\title{
Archaeologia
}

http://journals.cambridge.org/ACH

Additional services for Archaeologia:

Email alerts: Click here

Subscriptions: Click here

Commercial reprints: Click here

Terms of use : $\underline{\text { Click here }}$

\section{Notes on Edward Grimston, Esq. Ambassador to the Duchess of Burgundy}

\section{A. W. Franks}

Archaeologia / Volume 40 / Issue 02 / January 1867, pp 455 - 470

DOI: 10.1017/S0261340900002599, Published online: 25 January 2012

Link to this article: http://journals.cambridge.org/abstract S0261340900002599

How to cite this article:

A. W. Franks (1867). Notes on Edward Grimston, Esq. Ambassador to the Duchess of Burgundy. Archaeologia, 40, pp 455-470 doi:10.1017/S0261340900002599

Request Permissions : $\underline{\text { Click here }}$ 
Notes on Edward Grimston, Esq. Ambassador to the Duchess of Burgundy. By A. W. Franks, Esq., Director.

IT may be of interest to the Society to collect together such notices as occur of Edward Grimston, the ambassador to the Duchess of Burgundy, and the person represented in the interesting portrait by Peter Christus.

By the kindness of the Earl of Verulam, I have been able to make use of various documents, apparently unpublished, which assist in throwing some light on the ambassador's history.

The family of Grimston, of Grimston in Holderness, was of great antiquity, and claims descent from Sylvester de Grimston, standard-bearer to William the Conqueror at the Battle of Hastings. The name does not however appear in the Roll of Battle $\Lambda$ bbey. Edward Grimston, as shown by a document printed below, claimed to bear the arms which had been borne by his ancestors for 400 years, which would carry them back even before the Conquest.

The Grimstons of Grimston, or Grimston Garth, in Holderness, it may be stated, bore the arms, Arg. on a fesse sa. three mullets pierced or. The subject of our notice and his descendants, being a junior branch, differenced the coat by the addition of an ermine spot sa., and in this form the arms appear both on the front and back of the portrait. The coat in its undifferenced state is given in the Roll of Arms temp. Richard II. as borne by Gerard de Grymston, probably the person called in the pedigrees Sir Gervaise Grimston of Grimston, who died without issue. He was succeeded by his brother Walter, whose son William Grimston of Grimston, had three sons: from the eldest of them, Thomas, descend the Grimstons of Grimston.

The second son, Robert, seems to have settled in Suffolk during the reign of Henry V.; he married a daughter of Sir Anthony Spilman, of Suffolk, which match is said to have been the cause of his removing to that county. ${ }^{\text {a }}$ There was, however, an early connection with the De la Poles, who, starting from Hull, had acquired lands in Norfolk and Suffolk. The Grimstons living in Holderness may have had transactions with the wealthy merchants of Hull, and in the 16th of Richard II. we find that Gerard de Grimston had given a bond for $£ 50$ to Sir Michael de la Pole.

The son of Robert Grimston was Edward Grimston, the subject of this notice. Either he or his father may have adopted the difference of an ermine spot in

a Reyce, in a manuscript pedigree, gives 1421 as the date of the settling in Suffoll.

b Kal. and Inv. Exch. ii. p. 45. 
their coat of arms ; and, as we find two coats ascribed to the name of Spilman or Spelman in which ermine charges occur, it is not impossible that the ermine spot may have been derived from that source.

Edward Grimston is described as of Rishangles in Suffolk, in which parish it may be mentioned that the De la Poles held a knight's fee, and from a document which will be hereafter noticed it would appear that he had been in the service of the Earl of Suffolk during the minority of Henry VI. that is before 1442.

The first notice of him that I have found in the public documents is in 1441 . On the 25th November, 20 Henry VI. (1441), a warrant was issued to the treasurer and chamberlains to pay to Stephen Wilton, Doctor of Laws, "which goeth in the King's service to the Duchess of Burgundy and others," c. marcs. A similar warrant was issued to pay Edward Grymston and William Port, to either of them £20, as a reward to go " in the said message with the said Master Stephen." Three days afterwards however it appears that William Port was indisposed to go, and the sum to be paid to him was ordered to be divided between Wilton and Grimston, 20 mares to the former, and 10 marcs to the latter. ${ }^{\mathrm{a}}$

The mission to the Duchess of Burgundy was no doubt connected with the commercial treaties between England and Flanders. The great importance of an unrestricted trade between the two countries had led to a number of truces and treaties, infringed from time to time by the misconduct of the merchants of one or other country, or temporarily suspended by wars between the rulers of the two countries. So important however was the commerce to both parties that we occasionally find that a provision was made for the continuance of commercial intercourse, even though the rulers of the countries should be at war.

The Duke of Burgundy had been on the side of England; but, in 1435, annoyed with the second marriage of his brother-in-law the Duke of Bedford, and other causes, he concluded the treaty of Arras with France. This greatly exasperated the English, who, as a reprisal, went so far as to put to death some of the merchants from the Low Countries then in London. ${ }^{b}$ The English took Ardres and the Burgundians Crotoy. The injury however which ensued to the commerce of Flanders induced the Duchess of Burgundy to write to her cousin, the King of England, to ask that commercial intercouse might be renewed. Commissioners were appointed on each side, ${ }^{c}$ and a treaty for commercial intercourse was concluded for three years at Calais in 1439 , to terminate November 1,1442 . $^{\text {d }}$

\footnotetext{
a Nicolas, Proc. Privy Council, v. 169, 176

c Rymer, x. 713.
}

b Paradin, Annales de Bourgogne, p. 768.

d Rymer, x. 736 . 
In 1440, Wilton and Chyrch went to Bruges to settle the claims of damages made on either side since the treaty of Arras; this they completed on the 17th June, 1440, and their award was confirmed by the King, 12th July following. ${ }^{3}$

In January 1444, the Earl of Suffolk and other Commissioners met at Tours to negotiate a truce with France as a preliminary to a peace, in consequence of the proposed marriage of Henry VI. with Margaret of Anjou. The truce was signed May 28, 1444, and the Earl of Suffolk, having been created a Marquess, was authorised to espouse the Princess of Anjou as proxy for the King. The espousals were celebrated at Nancy, and the Queen arrived April 9, 1445. Edward Grimston seems to have been connected with this business, as on the 17 th of the previous August a payment of $146 \mathrm{l}$. $13 \mathrm{~s}$. $4 \mathrm{~d}$. was made from the Exchequer to the Marquess of Suffolk, who, by the King's command, proceeded abroad to bring over and safely conduct the Queen to the King's presence, "in money paid to him by the hands of Edward Grymeston in part payment of his wages of $4 l$. 10s. a day for two months for going upon the business aforesaid." " Grimston was likewise employed to pay sums to two minstrels of the Duke of Milan, and to John de Surenceurt, an esquire of René of Anjou, who had come to the Queen's coronation. ${ }^{c}$

It is probable that in recompense of his various services, and also perhaps by the favour of the Earl of Suffolk, Grimston obtained on the 8th September, 1445, from the King, in conjunction with John Lampet, Lieutenant of Avranches, the reversion of the Ward and Captaincy of the castle of Valoignes in Normandy. The original grant is in the possession of the Earl of Verulam, and runs as follows :-

Henry par la grace de dieu Roy de france et dangleterre a tous ceulx qui ces presentes lettres verront salut. Comme des se tiers jour du mois davril derniers passe pour consideracion des bons et aggreables seruices que nous a fais de long temps ov fait de nos gueures nostre ame et feal escuier Jehan Lampet lieutenant a Avranches et conflans de ses sens loyalte diligence et bonne experience nous lui eussions done et ottroye a terme de sa vie la garde et capitainnerie de nostre chastel de Valoingnes vacans lors comme len disoit par la mort de Jehan de Robessartd lainsne chevalier et depuis avons eu congnoissance quil estoit encore en vie par quoy le don que en avions fait au dit Jehan Lampet na aucunement sorti son effect Et pur ce nous ayans en memoire icelui don du quel ne voulons estre frustre icelui eseuier mais icelui valoir en temps et en lieu Savoir faisons que pour les causes devant dictes et consideracions des bons et loyaulx services que Edward Grymeston escuier nous a faij depieca des nostre jeune aage en la compaignie de nostre treschier et
a Rymer, x. 791.
b Devon, Issues, p. 448.
c Ibid. p. 452.

d In 1432 Thierry de Robessart was captain of garrison at Saint-Sauveur-le-Vicomte. Joursanvault Papers, p. 227.

In 1433 Jehan de Robessart was captain of garrison at Caudebec. Ibid. p. 228.

VOL. XL.

$3 \mathrm{~N}$ 
tresame cousin le marquis conte de Suffolk grant maistre de nostre hostel si comme encore fait un chascun jour A iceulx Jehan Lampet et Edward ensemble et au seurvivant deulx deux avons donne et ottroye donnons et ottroyons de grace especial par ces presentes icelui office de garde et capitainnerie de nostre chastel de Valoingnes que a tenu et tient de present le dit Jehan de Roberssart pour en joir par les dessusdis et survivant diceulx a terme de la vie deulx deux et dun chascun deulx comme dit est tantost apres le trespas du dit Jehan de Roberssart aux gaiges droiz franchises prouffiz et emolumens acoustume 3 Et ainsi et par la forme et maniere que en a joy et joist encore icelui de Robessart Et avec ce a telle charge et retenue de lances et darchiers qui par nous ou noz lieuxtenants ou commis leur sera selon les temps ordonnee Pourveu que les dessusdits Jehan Lampet et Edward ne prendront ne auront de nous tous deux autres gaiges pour raison dudit office de garde et capitainnerie quil est acoustume Et donnons en mandement au bailli de Cotentin ou a son lieutenant que prins et receu des dis Jehan Lampet et Edward et dun chascun deulx le serment en tel cas acoustume il les mette et institue ou face mettre et instituer de par nous en possession et saisine $\mathrm{du}$ dit office et dicelui ensemble des droiz gaiges franchises prouffiz et emolumens dessus dits et au dit office appartenants les facent seuffrent et laissent joir et user plainnement et paisiblement par la maniere dessusdit et a eulx deux a chacun deulx obeir et entendre par tous ceulx quil appartendra es choses touchans et regardans icelui office en leur faisant iceulx gaiges paier baillier et delivrer par ceulx quil appartendra et qui les ont acoustume de paier aux termes et en la forme et maniere acoustumez Lesquel3 ainsi paiez nous voulons par rapportant avec ces presentes ou le vidimus dicelles fait soubz seel royal ensemble quietances des dessusdit Jehan Lampet et Edward ou de lun deulx pour lautre estre allonez es comptes et rabatuz de la recepte de celui ou ceulx qui paiez les aura ou auront par noz amez et feaulx les gens de nos comptes a Rouen Aux quelx nous mandons et commandons que ainsi le facent sans contredit ou difficulte aucune En tesmoing de ce nous avons fait mettre nostre seel a ces presentes. Donne en nostre chastel de Wyndesore le viijme jour de Septembre lan de grace mil cccc quarante cinq et de nostre regne le xxiij ${ }^{\text {me }}$.

Par le Roy, monsieur le marquis Conte de Sulffolk, messire Emond Hunguerfford, et autres presens.-JE. RrveL.

Attached to a wide parchment label a fragment of a seal of white wax, apparently the counterseal of the French great seal of Henry VI, representing an angel holding two sceptres and the shield with the arms of France and England. ${ }^{a}$

We next find Grimston once more employed in a mission to Burgundy, and at a time that is of some interest, as being that of the date on the portrait by Peter Christus. (Pl. XXVI.)

The treaty for commercial intercourse with Flanders had been made for three years in 1439 ; $^{\mathrm{b}}$ and December 24,1439 , ambassadors were appointed (including Stephen Wilton) to meet the envoys of Flanders for the prolongation of the treaty,

a Engraved in Trésor de Numismatique et de Glyptique, Sceaux des Rois de France, pl. xi. fig. 3.

$$
\text { b Rymer, x. } 736 .
$$


Vo1. XL. P1. XXVI p. 458.

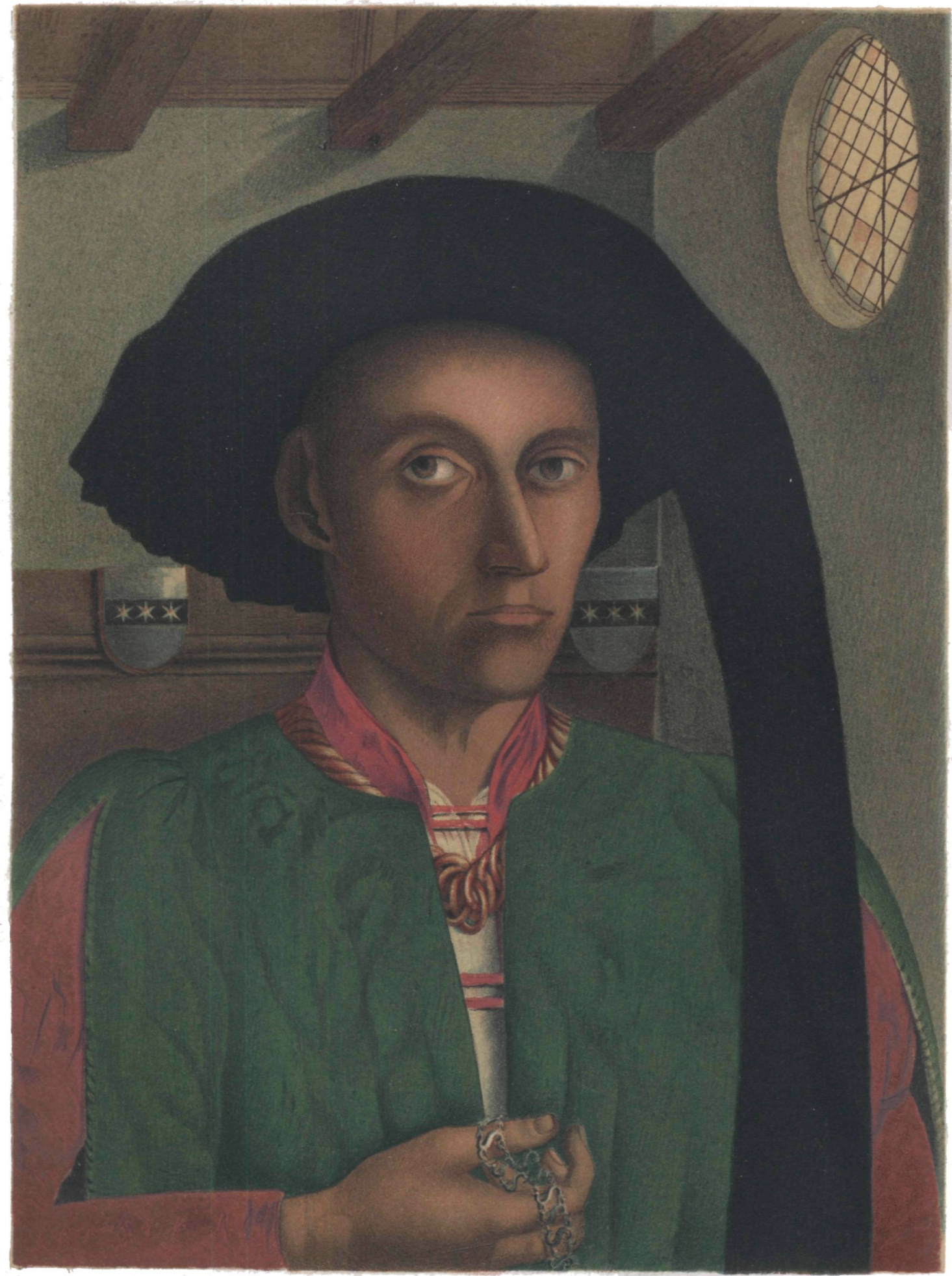

EDWARD GRIMSTON, 1446.

from the original Portrait at Gorhambury. 
which was done for five years, ${ }^{a}$ so as to expire 1st November, 1447. In 1446 a meeting was held at Calais, and on the Ath August the treaty was renewed for twelve years, so as to expire 1st November, 1459. ${ }^{\text {b }}$

This however controlled more especially the commercial intercourse between the two countries. In 1443, the Duchess of Burgundy, having received full powers from her husband, concluded with the Duke of York, Lieutenant and Governor-general for the King of England beyond the seas, a truce, from which either party could only recede by giving three months' notice. 'The letters patent of the Duchess are dated 23rd April, 1443. On the 1st of February, 1446, letters of safe-conduct were given by Henry VI. to John de Luxembourg, Bastard of St. Pol and lord of Halburdyn, and his company, who had probably come on the business of the treaty. The truce was accordingly renewed, as appears by the Duchess of Burgundy's declaration, dated at Brussels 12th July, 1446, and by the renewal, each party was to give one year's notice before abandoning the truce. On the 14th July the King issued his letters patent, reciting the fact of the new treaty recently concluded, and appointing Master Thomas Kent, doctor of laws and clerk of the Council, and Edward Grymeston " ad tradendum et deliberandum dictas literas nostras una cum aliis ejusdem datæ facta dictarum abstinentiarum tangentibus præfatæ consanguineæ nostræ vel potestatem sufficientem in ea parte habentibus vel habenti Recipiendo literas super ipsis abstinentiis confectas sub sigillo ejusdem nostræ consanguineæ continentes tenorem de verbo ad verbum ejusdem sedulæ signatæ per Dominum Johannem Luxembourg Militem Bastardum Sancti Pauli et dominum de Habourdyn." "

It is therefore probable that Kent and Grimston went to Brussels, where the Duchess then was, and it is possible that it was in that eity that the portrait was painted by Peter Christus.

On the 14th May, 1447, the Duchess of Burgundy issued her letters patent, ${ }^{\mathrm{f}}$ in which, after reciting the treaty of the Duke of York, and stating that she has lately had speech with some servants and subjects of the King of England, "lors estans pardevers nous," she appointed the Bastard of St. Pol and Master Rolland Pippe to communicate with the King of England or his officers. The truce was then prolonged for four years.

In December 1447, we find on the Issue Roll notice of a payment to Francis l'Arragonois, lately made knight of the garter, made to him by the hands of Hennage, servant of Edward Grimston, as a gift from the King to discharge the

\footnotetext{
a Rymer, x. 750.

a Ibid. xi. 116.
}

b Ibid. xi. 140.

e Ibid. xi. 138.

$3 \times 2$ c Ibid. xi. 24.

f Ibid. xi. 171. 

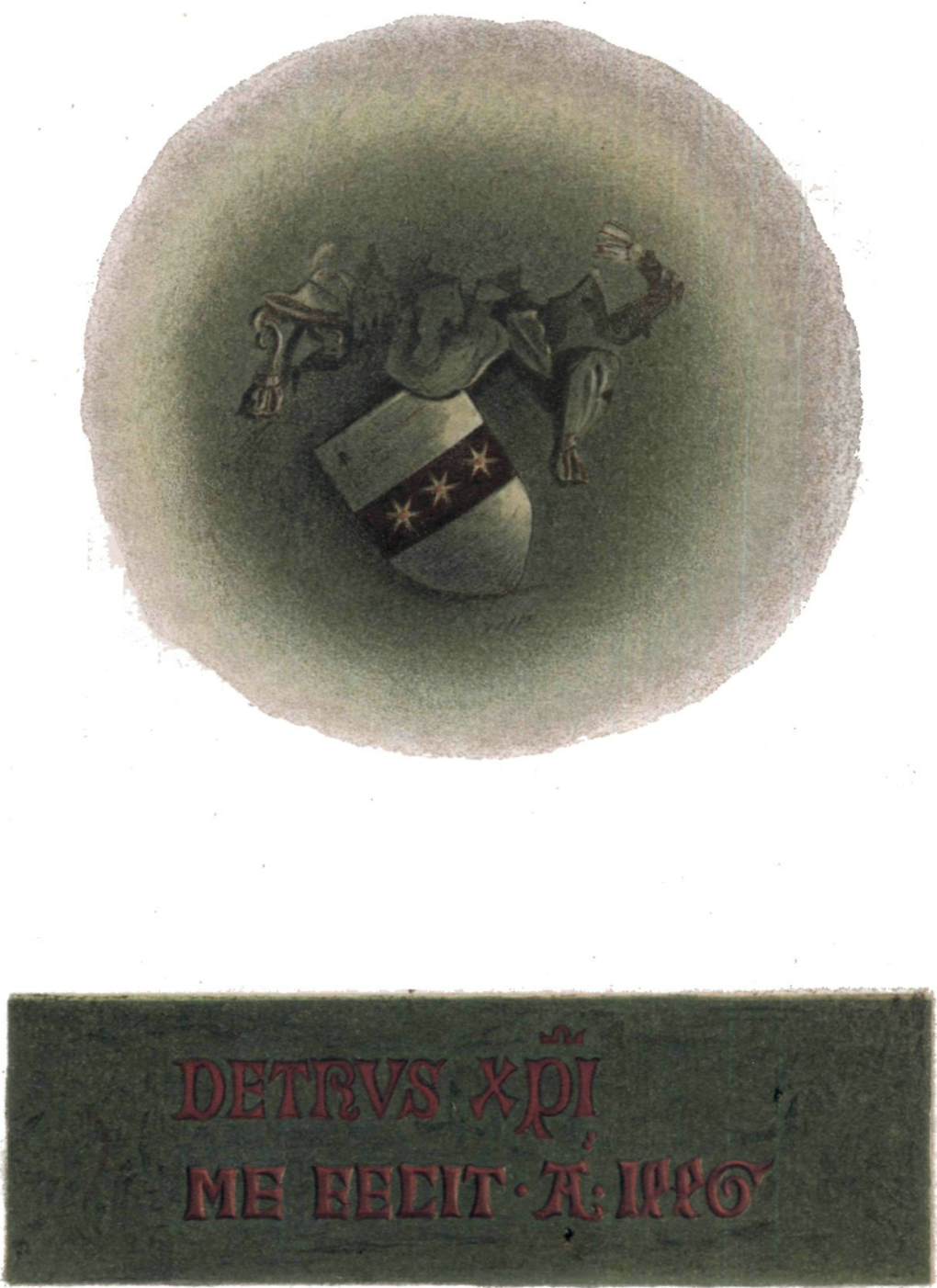

ARMS OF EDWARD GRIMSTON AND SIGNATURE OF ARTIST. 
fee due by him as K.G. to St. George's Chapel. ${ }^{2}$ This was Sir Francis de Surienne, commonly called the Arragonese, who was elected K.G. on the 27th November, 1447, and installed 8th December following.

In consequence of infractions of the truce between France and England and between England and the Duchess of Burgundy, the King of England appointed on the 25th October, 1448, as ambassadors Sir Humphrey Stafford, Sir John Mareney knight, Master Robert Stillington and Master Richard Wetton doctors of law, together with William Pirton and John Wodehous esquires, to meet at Calais, or any other convenient spot, in order to see to the correction, punishment, reparation, and reformation of these infractions, and to require and obtain the same from the other sides ; this was to be done " sine strepitu et figura judicii," by consent of both parties. ${ }^{\mathrm{b}}$

The meeting was held at Calais in November 1448, and prorogued to the 4th May, 1449; the ambassadors of the Duchess were the Bastard of St. Pol, Henry Uttenhove, and John Postel. ${ }^{c}$

This brings us to the year 1449 , the date of the instructions printed above. From the proceedings of the Privy Council ${ }^{\mathrm{d}}$ it would appear that on the 17th March, 27 Henry VI. (1449), William Pirton, lieutenant of Guines, and Edward Grymeston received instructions to go to the Duchess of Burgundy and with due reverence remonstrate at the prohibition of the introduction of English cloth; and, after reminding her of the King's negociations with " they of Holland and Zealand," and the truce for free intercourse concluded at Rouen by the Duke of York, and the truce between England and France, in which the Duchess is comprised, they are to state that the ordinance cannot be considered a restitution of attemptates. The instructions then go on as follows:-

"As the King has now called the third estates of his land and they be assembled at the city of London for his Parliament, the said third estates have piteously complained upon the said ordinance, and besought the King that he would ordain, if the said ordinance were not put aside without delay, that no merchandise of the said countries should be received or attempted in this land, but be forfeited in case it be brought hither, and so they beseech the King to require the said Duchess to put aside the ordinance.

" Inasmuch as there is a report of arms at St. Omer and concourse of people, and as divers habiliments of war have been ordained and made in divers places of that obeissance, the said ambassadors shall move of their own selfe, speak and
a Devon, Issues, p. 460.
b Rymer, xi. 218.
c Ibid. xi. 220.
d Nicolas, Procedings of the Privy Council, vi. 69.
e Rot. Parl. v. 150, 151. 
commune upon this matter, and feel by all means they can to what intent the said things be ordained, for the noise and renown is that under the said colour divers enterprizes be imagined and taken in hand."

There are some further instructions which terminate with the statement that if the Duchess "will ordain and depute her people, as well for the quatre membres as other, to have communication upon the said matters, the King will be ready also to ordain his commissaries."

Pirton and Grymeston are not here called ambassadors, but were rather accredited messengers.

In consequence probably of the Duchess having agreed to treat, Sir John Marney, Kent, Pirton, Grimston, and Wodehouse, were appointed ambassadors, commissioners, procurators, and special messengers, to arrange the quarrels "sine strepitu et figura judicii." a The instructions they received are printed above.

On the 28th July the King appointed no less than fifteen persons, the chief of whom were Lord Dudley, Thomas Kent, and Thomas Thirland, as ambassadors to treat for commercial intercourse, and especially concerning the sale of wools and fleeces, and at the same time Lord Dudley and Thomas Kent were appointed ambassadors to treat concerning the reparation of infractions of the truce.

In these appointments the name of Edward Grimston is not mentioned, and it is probable that he was otherwise engaged, having been sent from the King of England to the King of France. The relations between the two monarchs had become very unsettled in consequence of the taking of Fougères by the English under Sir Francis de Surienne. That Grimston was sent to the King of France about this time appears from the answer made by the Duke of Burgundy on the 24th July, 1449, to Charles VII. who had sent ambassadors to the Duke to ask his advice as to how the King should act towards the English, they having broken the truce. ${ }^{\mathrm{b}}$

The Duke says that the ambassadors have told him "que puis nagaires le roy avoit recues lettres de son nepveu dangleterre contenant creance sur Edouart Grimeston et aussi plusieurs lettres de duc de Sombreset," \&c.

The subject of Grimston's mission is not given, but it seems to have been unfortunate as affecting his subsequent career, for we do not find him again employed in diplomatic affairs. He was about also to lose his patron the Duke of Suffolk, who, after being impeached by Parliament, committed to the Tower,

a Rymer, xi. 229.

b Reply of the Duke of Burgundy to the Ambassadors of Charles the Seventh, King of France. Stevenson, Wars of the English in France, i. 264. 
and released, was miserably put to death in a boat in Dover Roads, May 2nd, 1450. After the Duke's death, the Commons assembled in Parliament presented a petition for the removal of certain persons from the King's presence; among them are the Duke of Somerset, the widowed Duchess of Suffolk, the Bishop of Chester, Lord Dudley, and various other persons including "Edwarde Grymston, late of London, squier," and begging that they may not receive any of their salaries from 1st December, 1450. ${ }^{\mathrm{a}}$ It is probably to this time that may be referred a curious petition in Grimston's own hand, of which the original is preserved among the records of the Earl of Verulam, and which may therefore never have been presented. It is in the following words :-

To the Kinge our sovereign lorde.

Moste Cristien prince and oure aller moste dradde sovereign lord, I your humble true liegeman Edward Grymeston, constreigned of necessite at this tyme to withdrawe my pouere persone for drede of persones that bene hasty and hote and list not to knowe nor undirstande the trouthe of my desertes, and not for none offence that ever I dydd seid laboured or was knowynge of yn wille thought or ymaginacion ayenst the weelez of youre moste noble persone or of your Realme yn any wise, Beseche humbly your Roialle mageste that for my true acquitell unto youre highenes ye like to foryiffe me, Allethough I enhardie me by wey of meke supplicacion to write for my trouthe and declaracion unto youre grete rightwosnes, By the whiche as lowly as ever didd true liegeman I beseche youre grace that my merittes may truely be undirstande knowen and so pupblisshed \& shewed unto the generallte of this your highe court of parlement, To the whiche I crye and beseche our mercyfull lord that alle knoweth that aftir my true menynge rightewosly undirstande I may have that I have deserved and none othirwise. And for as muche as I am enformed that by my goinge diversez tymes over the see by the highe commaundement and ordenaunce of you sovereign lorde and of youre fulle noble counceille, and specially yn this my laste viaige unto youre uncle and adversaire of Fraunce, in the conceites of murmureux and misunderstandinge persone 3 I am noyssed and disclaundred with grete blame and charge that I shulde receive on that partie grete and excessive sommez of goode, And ys supposed that I shulde labour knowe and be assentinge to thinges that shulde be hurt and preiudice to you sovereign lord and youre Realmez as yt ys seid, that godd defende, In the whiche viagez moste dradde sovereign lord and yn everich of theme by the feithe and liegeaunce I owe to you and ever shalle I have allewey done my true parte laboure and devoire aftir myn instruccions yeffen me by thadvise of your noble and true counceille to execute and fullefille the chargez and commaundment that $I$ have hadde, And therof allwey made my feithefulle and true Reportes to my lordes of your counceille, And yn esspecialle of this last right costageux and aventreux viage that $I$ went unto youre seid uncle and adversarie by their allers ordeignnaunce and commaundement sore ayenst my wille saving for youre highe displesaunce and their allers so as of recorde I profved grete part of my pouer goode to have bene discharged thereof at tyme and couthe not, The whiche seid viage I toke upon me and fullfilled my charge to my grete coste and laboure. And yn grete aventure and daunger of my lyffe as yt

a Camden Suciety, Trevelyan Papers, i. 60. 
ys welle knowen, And alle the convey of my seid viage as welle the reporte and declaracion alle alange in what timez $I$ spake unto youre seid uncle and what answers he yaffe me as of alle the demaundes answers and comunicacions that I hadde yn any wise with him or his counceille word for word as ferforthe as I couthe thinke or ymagine dayly and yn continent I wrote theme forthwith of myn own hande to that ende that so myn othir chargez that by the ordenaunces and commaundementes before seid I hadde to the Duchesse of Bourgne I myght the rather and more spedely sende yt over to my lordes of youre counceille withouten delaye than to have abyden the lengthe of my comynge, So that by their highe wisdome thei might the more hastely provide for the remedies of that thereby mighte be undirstande was amys, And also that for my true acquitille the seid Reporte so writen of myn own hande might remaigne of recorde, the whiche by grete parte of my seid lordes was redde over alle alange and welle noted and examyned as $I$ trowe thei bene yitt remembred, Of the which services at my commyng home my lordes alle yaffe me a grete laude and thanke etc. And yn as muche, moste gracieux sovereigne lord, as I wote not whedir ye be remembred and have true knowlege of my seid declaracion I therefore presume and emboldisshe me upon your grace and benignite herewith to sende the same propre declaracion so writen of my pouere hande unto your highenes, Besiching humbly youre moste royalle persone that of youre grace and pitee ye like to undirstande the trouthe of my true service and menynge, And that ye like of your grate rightewosnes to commaunde and ordeigne yt to be showde and redde with this humble request unto the lordes and communs beinge now assembled yn this youre highe court of parlement, And yiff there be any erthely man what so ever he be that particulerly wille say or charge me with the receit of any manere of goode on that partie othir than I have certified un to my lordes of your seid counceille that your seid uncle and my lord of Somersett yaffe me at my departinge Or ferthermore wille sey that I laboured spake procured or by any mene was prive or hadde communicacion of any othir matere on the Franche partie other then by the seid declaracion I have truely writen as I couthe and at all tymez as welle hereof as of myn othir chargez for you sovereign lord yn alle wise made my true reporte unto my lordes of your counceille Or that sithens I was borne ynto this worlde yn that viage or any othir I ever was willinge knowinge and assentinge to any thinge that might rightwosly soune or be taken to any manere hurt or preiudice of you moste gracieux sovereigne lord or of youre lande yn any wise to myn understanddinge. Whensoever I may here or have knowlege of any suche particulere persone and that yt like your highenes that I may be herde and stande yn suerte of my pouer persone from the rigeure of persones withoute cause or reson eville disposed and advysed undir the proteccion of oure mercyfulle lord and of your grete rightewosnes I shalle not faille with youre noble leve as welle for my true liegeaunce as for the pouere worshippe of the blode that I am commen of beringe the same name and armes that I doo more than ccec yeres as yt may be proved, to comme and offre my body as youre true liegeman openly to preve and make goode the contrarie upon any suche persone that so wille or darre charge me yn suche wise as ye wille yiff me leve and as the case shalle require. Besechinge therefore you of youre most ample and speciall grace and semblably the goode wille of all that shalle here this humble request to accept my true feithe and liegeaunce to you wardes that with the grete mercy of oure lorde shall never faille, And that by the socoure and releeffe of your grete pitee and rightewosnes and your peoples 
true undirstandinge I your true humble subgette that wyllingly never trespassed to man on lyve but entended allewey my true service be not thus unrightwosly blamed nor withoute desert putt yn drede disclaundre and noyse to myne uttermoste reprooffe and undoinge. And that this myn humble and meke supplicacion and desire of iustice conceived and writen of myn owne hande withouten advise or counceille save of godd and of my true menynge for my true acquitaille may be taken aftir my playne and uncolured writing at alle tymes. And so to be understande pubblysshed and yiff yt like your grace enacted yn this present parlement at the reverence of godd and yn the wey of charite.

And for as much as for the causes beforeseyd and othir of goddes visitacion I nethir darre nor may comme to your highenes at this tyme yn my persone And that to the peoples understandinge this shulde not be thoughte no feyned supplicacion the more largely to verefie and to bynde me to that ys before writen I therfore feirfully have taken upon me undir the proteccion of youre highe magnificence to signe this with myn hande and with the pouere seale of myn armes for the more credence and recorde.

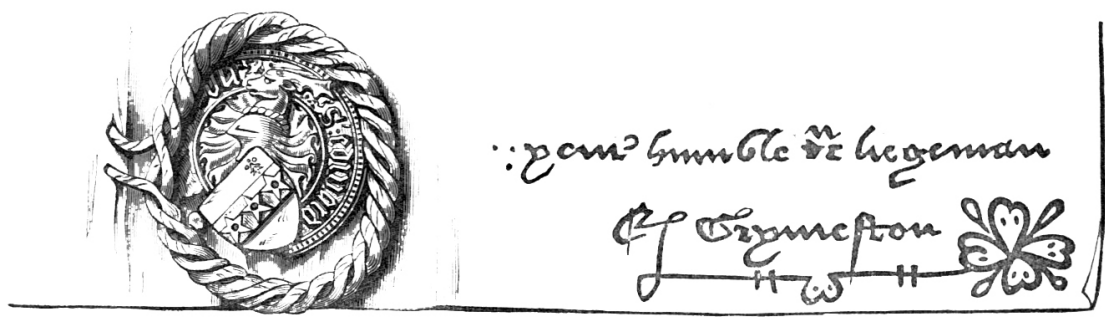

We next hear of Grimston as indicted with others at Rochester before the Cardinal of York, the Archbishop of Canterbury, and the Duke of Buckingham, ${ }^{\text {a }}$ in August 1451, in connection with Cade's rebellion.

In the former petition Grimston states that he has withdrawn himself, and he may very likely have been out of the kingdom. Another and probably later petition is preserved among Lord Verulam's archives from which it would appear that he had been for twenty-two months in prison, and it may therefore very fitly find a place here.

To the Kinge oure sovereign lorde.

Please it you oure moste dred souereign lord of your moste specialle grace piteuxly to considre the lange endured and undeserved sorows dredes $\&$ troublez with the inportables lossez of goode that causeles your humble true liegeman Edward Grymeston hathe suffred \& borne to his uttermost undoinge \& distruccion withouten the hasty relieffe of oure mercyfulle lord \& of youre grete pitee \& rightwosnes that by sum mene youre highenes like to ordeign and commaunde that he may be herd \& accepte to iustices to answere to any thinge that hathe bene or can be seyd or leyde unto him, the whiche he hathe sued \& offred him selffe to by the space of xxij monethes yn as large wise as ever did poure liegeman, but he ys so aloigned \& delayed therfro that

a Ellis, Original Letters, 2nd Ser. i. 113. 
nethir by your specialle writinges nor messages to your jugez nor othire wise he can atteign therto by what menez nor for what cause it ys not undirstande Besechinge therfore humbly youre benigne grace that of your grete rightwosnes \& yn tendir consideracion of the sorowfulle premissez with many other adversitez that your seid suppliant hathe lamentably suffred onely for lak of iustices that yt may like your highenes to commaunde your jugez of your benche straitly by your mouthe or by your specialle writinges to attende and hastely to procede to his deliverance So as aftir his arreignement by your specialle grace \& commandes he may go at large under baille upon sufficiaunt suerte to suche tyme \& place as by your seid iugez or any of them shalle be lymyted \& graunted for his deliverance And that for the sone expedicion thereof ye like hereupon to graunte and commaunde suche specialle lettres fro your highenes un to your seid jugez as shall be thoughte necessarie for the diligent spede therof So as of your grete pite and rightwosnes your humble true liegeman be not finally distroyed by no lenge delayes fro iustices at the Reverenc' of oure lord whome he shalle evermore pray for your moste noble astate.

This petition is neither dated, signed, or sealed, and may have been only a draft of one actually sent. It is in the same hand as the other.

We must now turn to the domestic relations of Edward Grimston. Among the papers in the Earl of Verulam's possession are some memoranda which appear to have been communicated to Mr. Warner of Lincoln's Inn, 12th February, 1599, by Williamson, a mercer dwelling by St. Magnus in London, on the authority of an old kalendar which would appear to have been in a manuscript which had belonged to the parish church of Eye in Suffolk. One of the entries seems to relate to the first wife of Edward Grimston, and at any rate has been considered to do so by the compiler of the notes; it is somewhat obscure and is as follows:-

"Obitus venerabilis femine Alicie quondam uxoris E. Grimeston ab infanti excellente ducissa postea generose magnifice Margarete Reginæ que etiam et virtutibus fuit induta et obiit 1456."

From a description of the tomb of Edward Grimston, which will be given hereafter, it is not improbable that the coat of this lady was $G u$. three bars gemelles arg. This was a form of the coat of Bensted, and was also borne with additional charges by the names of Walshe, Inglos, and Thornhill. It was also a foreign coat, being ascribed to the families of Averton, Fosseux, Noyelle, $\mathbf{S}^{t}$. Cheron, $\mathbf{S}^{t}$. Julien, Toulonion, and Wyon.

Among the papers at Gorhambury is a copy of a deed dated 26th September, 38 Henry VI. (1459), which appears to be the marriage settlement of Edward Grimston with his second wife Mary, daughter of Sir William Drury by Katherine Swynford; the latter was at the time of the settlement the wife of Thomas Cursun, Esq. This document is as follows:-

Hec Indentura facta $\mathrm{xxvj}^{\text {to }}$ die Septembris Anno Regni Regis Henrici $\mathrm{vi}^{\mathrm{ti}}$ post conquestum VOL. $\mathrm{XL}$.

30 
xxxvijo ${ }^{0}$ inter Edwardum Grymeston Ar. ex parte una et Thomam Cursun Ar. dominam Catherinam uxorem eius nuper uxorem Willielmi Drury Militis et Thomam Drury armigerum filium et heredem eiusdem Willielmi ex parte altera testatur Quod cum idem Thomas Drury se agreavit et concessit solvere eidem Edwardo et assignatis suis centum marcas legalis monetæ Angliæ et iidem Thomas Cursun domina Catherina uxor eius et Thomas Drury ultra illas centum marcas se agreaverunt et concesserunt solvere eidem Edwardo et assignatis sive executoribus suis Quinquaginta libras legalis monetæ Angliæ ad maritagium Marie sororis eiusdem Thome Drury unius filiarum predicti Willielmi et domine Catherine Quam idem Edwardus (gracia divina mediante) ducet in uxorem. Quibusquidem centum marcis per predictum Thomam Drury eidem Edwardo impostea solvendis modo et forma quibus sequitur videlicet viginta marcas nunc die et tempore solemnisacionis maritagii predicti idem Thomas Drury eidem Edwardo solvet Et ad festum Sancti Michaelis Archangeli quod erit Anno domini millessimo quadringentessimo sexagesimo decem libras Et ad festum Sancti Michaelis Archangeli extunc proxime sequentem decem libras Et ad festum Sancti Michaelis Archangeli extunc proxime sequentem decem libras Et ad festum Sancti Michaelis Archangeli extunc proxime sequentem decem libras Et ad festum Sancti Michaelis Archangeli extunc proxime sequentem tresdecem libras sex solidos et octo denarios Pro qua quidem summa centum marcarum idem Thomas Drury inveniet sufficientem securitatem per separalia scripta obligatoria pro qualibet solucione eidem Edwardo et executoribus suis annuatim ad festa predicta solvenda predictasque quinquaginta libras eidem Edwardo et executoribus suis modo et forma quibus sequitur solvend' videlicet quod cum idem Thomas Drury annuatim solverit eisdem Thome Cursun et domine Catherine uxori sue ad terminum vite ejusdem Catherine decem libras pro manerio de Lawnes in comitatu Suffolk Quod quidem manerium de hereditate ejusdem Thome Drury extitit Ita concordatum est quod iidem Thomas Cursun et domina Catherina uxor ejus et Thomas Drury solvent ad festum Sancti Michaelis Archangeli proxime futurum eidem Edwardo sive assignatis suis quinque marcas legatis monete partem de predicta annuali redditu decem librarum eidem domine Catherine pro predicto manerio de Lawnes solvenda et ad festum Sancti Michaelis Archangeli ad tunc proxime sequentem quinque marcas Et sic de anno in annum ad idem festum Sancti Michaelis Archangeli quinque marcas quousque predicta summa quinquaginta librarum plenarie fuerit persoluta Pro qua quidem summa quinquaginta librarum eidem Edwardo et executoribus suis solvenda modo et forma superius recitatis inter partes predictas concordatum est Quod Johannes Clopton Armiger et omnes alii si qui fuerint ad usum predicte domine Catherine sive Thome Drury de et in dicto manerio de Lawnes cum suis pertinenciis feoffati per suum sufficiens scriptum sigillatum dabunt et concedent eidem Edwardo et assignatis suis quendam annualem redditum quinque marcarum annuatim exeuntem de predicto manerio cum suis pertinenciis habendum et percipiendum eidem Edwardo et assignatis suis quousque quinquaginta libræ plenarie persolvantur Quod quidem scriptum facient et eidem Edwardo deliberabunt ante festum Nativitatis Domini proxime futurum Ulterius concordatum est quod predictus Johannes Clopton nec aliquis sive aliqui eorum qui de dicto manerio cum suis pertinenciis sunt feoffati permittent seu permittet aliquod recuperari per breve de forma donacionis indiscender sive per aliquod aliud breve ad sectam predicti Thome Drury sive alicujus aliæ personæ versus ipsos sive aliquem eorum sive aliquo alio modo extra eorum possessionem manerium predictum recuperare sive devolvere quousque predictæ quinquaginta libræ modo et forma antea recitatis integre persolvantur Et 
ad omnes istas convenciones ex parte predictorum Thome Cursun et Domine Catherine et Thome Drury bene et fideliter perimplendum iidem Thomas Cursun et Thomas Drury per separalia sua scripta obligatoria de dato presencium separatim teneantur eidem Edwardo in centum libras sterlingorum Qui quidem Edwardus pro se et executoribus suis concedit quod si omnes convenciones et soluciones ex parte predictorum Thome Cursun et Domine Catherine et Thome Drury sint integre solutæ et perimpletæ quod tunc predicta separalia scripta obligatoria centum librarum vacua sint et quodlibet eorum sit vacuum et nullius valoris. In cuius rei testimonium partes predictæ sigilla sua alternatim apposuerunt. Data die et anno supradictis.

By this marriage Grimston not only became in some measure connected with the house of Lancaster, but also with the Duke of Suffolk, if there be any truth in the surmise that Philippa Chaucer, wife of the poet, was sister to Katherine Swinford, Duchess of Lancaster, William De le Pole being grandson of Philippa Chaucer, and Mary Grimston great-grandaughter of the Duchess of Lancaster.

By his marriage with Mary Drury Edward Grimston had a numerous progeny, five sons and three daughters, who are thus noticed in the memoranda above alluded to.

John, the first gotten sonne of Edwarde Grimeston, Esquier, had of Mary his wief that was daughter to Wittm Drury, Knight, and of his wief dame Katheryn Swynforde, daughter of $\mathrm{S}^{r}$ Thomas Swynford that was sonne to $\mathrm{S}^{\mathrm{r}}$ Norman Swynford, that was husband to Dame Katheryn Swynford that was Duchesse of Lancaster, was borne the $\mathrm{xxi}^{\text {st }}$ daye of Aprill aboute viij of the clocke in the mornyng, the yeare of our Lorde 1461, the dominicall letter D.

Edward, the second sonne of Edward Grimeston, Esquire, and of the said Marie, was borne the xxiiij $^{\text {th }}$ daie of Marche our Ladyes even the annunciation quarter of the hower before ix of the clock at night, the year of $o^{r}$ Lorde 1461 , the dominicall letter $\mathrm{C}$.

Thomas, the thirde sonne of Edwarde Grymeston and Mary beforesaide, was borne the fyfth daye of Julie before $\mathrm{ij}$ of the clocke in the mornyng, the yeare of our Lorde 1463, the dominicall letter B.

John, the iiij ${ }^{\text {th }}$ sonne of the saide Edward and Mary, was borne the vith daie of August at fower of the clocke in the mornyng, the yeare of our Lorde 1464, the dominicall lettre G.

Christopher, the $\mathrm{v}^{\text {th }}$ sonne of the said Edward and Marie, was borne litell before $\mathrm{v}$ of the clock at nyght, the thirde day of Jule, the yeare of our Lorde 1466, the dominicall lettre F.

Anne, the first daughter of the said Edward and Marie, was borne the $\mathrm{xxvi}^{\text {th }}$ daie of Jule, $S^{t}$ Ann daye, midhower betwixt viij and ix of the clocke in the mornyng, the yeare of $o^{r}$ Lorde $1467, \mathrm{y}^{\mathrm{e}}$ dominicall letter $\mathrm{G}$.

Elizabeth, the second daughter of the saide Edward and Marie, was borne the xvij ${ }^{\text {th }}$ daye of November at vij of the clock in the mornyng, the yeare of our Lorde 1468, $\mathrm{y}^{\mathbf{e}}$ dominicall letter B.

Alice, the thirde of the said Edwarde and Marie, was borne the $\mathbf{x v}^{\text {th }}$ daie of February betwixt two and three after none, the yeare of $o^{r}$ Lorde 1469, the dominicall letter G.

And the said Marie, mother to all thes children before written, in her yonge and beavtevous 302 
yeares of xxvij passed christienly and devoutly to our Lordes mercy the vij daye of Marche then next following, in the yeare of our Lorde after the olde counte of England 1469, on Ashe Wedensdaye.

In a manuscript volume of the seventeenth century, preserved in the library of Lord Dacre, at the Hoo, lettered Reyce's account of Suffolk, no doubt by Robert Reyce, of Preston, in Suffolk, are some notes on the church at Thorndon, among which is the following description of the tomb of Mary Grimston (p. 218).

" These be the armes of Dame Katherine Sewynforde sometymes Dutches of Lancaster that by $\mathrm{Sr}$ Norman Sewynforde had a sonne and heire Sr Thomas Sewynforde knighte father to dame Katherine wyfe to $\mathrm{S}^{\mathrm{r}}$ Wylliam Drury Knighte the which $\mathrm{S}^{\mathrm{r}}$ Wylliam Drury and dame Katherine amonge others had Marye the wyfe of Edward Grimeston Esq ${ }^{\text {re }}$ whom God had endewed with greate vertue and bewtye and is heere interred the 6 daye of Marche $\mathrm{An}^{0} 1469$ on whose sowle God have mercy. Amen.

"Beneathe this Epitaphe lieth, in Brasse, the forme of a humane bodye in a wyndynge sheete, neere the which are eight children kneelinge, whereof 5 are bareheaded as sonnes and 3 in mourninge whooddes, all in brasse. Upon the very hiest parte of all was a greate escocheon quarterly of John of Gawnte as France and Englande, over all a lambeaux of 3 poynts ermyn empaled Sewynforde, $\arg ^{t}$ upon a chevron sable 3 bores heds coupped or. Somewhat lower was a single escocheon of Grimeston, argent upon a fesse sable 3 rowells or, in the canton poynte one ermyn. Upon the seconde corner Sewynforde as before. Upon the thirde corner beneathe Grymeston as before empaled Drurye $\arg ^{t}$ upon a cheefe verte 2 moollets or, pierced gules. Upon the $4^{\text {th }}$ corner beneathe Druery as before empaled Sewynford as before. Underneathe this corpes and eight children kneelinge was this wrytten, "Orate pro anima Marie Grimeston.' "'

The memoranda copied by Mr. Warner and already alluded to continue as follows :-

And the saide Edwarde Grymeston thelder was afterwarde wedded in the Abby Church of Eye (in the presens of my lorde the Duke of Suffolk and of my lady his wief syster to our soueraigne lorde King Edwarde the iiij ${ }^{\text {th }}$, to dame Phillip the lady and barrones Roos, daughter to the lord Tiptot and syster to the Earle of Worcester, the xxvjth daye of August yn the yeare of our lorde 1471.

The Lord Roos was attainted 4 th November, 1461, and died the same year, and his widow afterwards married Sir Thomas Wingfield, and thirdly Edward Grimston; by the latter she does not appear to have had any issue. 
The following curious petition was addressed to the King after the marriage by Edward Grimston and his wife; the original, which is undated, is preserved among the deeds in Lord Verulam's collection :-

To the Kyng oure alle most dradde liege lorde,-

Mekely besechethe and piteously compleynethe unto youre highenesse Edward Grymestone, Squier, and Philipe his wyfe, late the wyfe to Thomas late lord Roos, that by Reason of atteyndre of the same Thomas alle maners, londes, tenementes, Rentes, and possessions whiche were of the saide Thomas were forfaityd unto youre highenesse, by the whiche the saide Philipe was put from her dower and joyntoure that tyme to her due, amountynge to the yerely value of $\mathrm{M}^{1}$ marc' and more And youre saide highnesse, most graciously considering the nyghnesse of blode that the saide Philipe is unto your most roialle persone, that is to sey, doughter unto youre grete Aunte the lady Powys, that was suster unto the noble lady youre graundame the Countesse of Cambrigge, and noothinge that tyme had by Joyntoure or dower wherupone to lyve or to susteyne and fynde her and her childrein according to her honoure and worshipe of youre most noble and habundaunt grace graunted by youre lettres patentes bering date the ix day of Decembre in the first yere of youre most noble Reigne unto John late Erle of Worcestre and other to the use of the saide Philipe certain manors in diverse shires, estemed to the value of vijc marcs. Of the whiche somme in a parliament holden in the vij ${ }^{\text {th }}$ yere of your victorious Reigne there was resumed into youre handes certeyne of thoo maners to the yerely value of $\mathrm{iij}^{\mathrm{c}}$ marcs. After the whiche resumcione it lyked youre highenesse of youre most specialle grace to remember and consider the nyghenesse of blode beforeseide, with the honoure longinge therto, and that the said Philipe had nother dower, nor joyntoure, nor other goode to lyf by. And therupone, by thaduise of youre noble councelle, by youre lettres patentes under youre grete seale, bering date the $\mathrm{xxx}$ day of Juy\#, in the $\mathrm{vii}^{\text {th }}$ yere of youre seide victorious Reigne, gave and graunted unto the saide John late Erle of Worcestre, and to hir for terme of her lyfe, for sustentacione of her and her childrein, and in lieu of her ioyntour and dower beforesaide, the maners of Uffyngtone, Wragby, \& Estringtone, in the Counte of Lincolne, the maners of Orstone, Warsope, and Ekeringe, in the Counte of Notyngham, the maner of Setone with the Annuite of the priore of Wartre, in the Counte of Yorke, the maner of Adderley with Sponley in Shropshire, the maner of Estbourne with the hamelet of Hechingtone, in the Counte of Sussexe, that some tyme were longing to Thomas late lord Roos her husbond, the whiche maners with th' appurtenaunces be not to the value of ccec marcs. And semblably it lyked youre highenesse, in the viii ${ }^{\text {th }}$ yere of youre Reigne, by youre other lettres patentes, to graunte the same maners unto Sir Thomas Wyngfelde and her, that tyme her husbonde, for terme of her lyfe, Soo that in tymes thoo maners that youre saide suppliauntes clayme and occupie have passed youre grete seale, of which maners noght exceding to the value of ecce marcs the saide Philipe in her pure wydowhode hath yeven and graunted to the mariage and sustenaunce of hir ij doughters a the somme of $\operatorname{lxxx}^{\text {li }}$ during hir lyfe, So that the residue therof will unnethe suffice to her resonable sustenaunce, with charges requisite and incedent to the same. Please it youre highnesse, the premisses considered, atte reuerence of all myghty god, by the advyce and assent of the lordes spirituatt and temporatt and

a Elenor, who married Sir Robert Manners, and Isabel wife of Sir Thomas Everingham and others. 
Comens in this present parliament assembled, and by auctorite of the same, to ordeyne, stablysshe, and enacte that the saide Philipe from hensforthe suerly, for terme of her lyve, have, possede, kepe, holde, and enjoye alle the forsaide maners and alle other the premisses with theire appurtenaunces, quietly and in pease, withoute interuptione or eny resumyng of them, or eny part of them, by eny meane hereaftre into youre handes, according to youre graunte last made to her therof, as is afforseide, to have for her sustentacione aforehersed, In as much as she and her childrein have none other thing wherupone to lyve. And youre saide suppliauntes shall ever pray to god for the good prospirite of youre most roialle persone.

Nothing more seems to be known of the life of Edward Grimston, and in the manuscript account of Suffolk by Reyce, already noticed, we find the following account of his tomb.

"In a hie tombe enarched in the walle of the chawncell there lieth in armor, havinge an escocheon of Grimeston on eache shoulder, with this epitaphe,

Hic jacet Eduardus Grimeston armiger quondam de Rishangles Lodge qui obiit die mercurii viz. vicessimo tertio die mensis Septembris anno domini 1478. Cuius anime propitietur Deus. Amen.

"In the first corner above one single escocheon of Grimeston as before; in the seconde corner above, Grimeston as before, empaled, gules 3 barres gemelles $\arg ^{t} ; \ldots$. in the thirde corner beneathe, Grymeston as before, empaled, Drury as before; in the $4^{\text {th }}$ corner beneathe, Grimeston as before, empaled, Typtofte, $\arg ^{t}$ a saltier engrailed gules."

The tomb of Edward Grimston is noticed in Davy's Suffolk Collections (Add. MSS. 19,090, f. 156) as being within the communion rails; the inscription which had been on the edge of the slab of the altar-tomb had disappeared, and of the figure of Grimston a fragment only - "his head and breast with his arms on his shoulders still remains in the church chest." Of the four shields at the corners of the slab the two upper ones alone remained. 